Original article

\title{
Susceptibility of native French elm clones to Ophiostoma novo-ulmi
}

\author{
Jean PINON ${ }^{a *}$, Claude HussON $^{\mathrm{a}}$, Eric COLLIN $^{\mathrm{b}}$ \\ a UR Pathologie forestière, INRA, 54280 Champenoux, France \\ ${ }^{\mathrm{b}}$ UR Écosystèmes forestiers, Cemagref, Domaine des Barres, 45290 Nogent-sur-Vernisson, France
}

(Received 7 June 2004; accepted 24 January 2005)

\begin{abstract}
More than 200 clones from native European elm species (U. minor, U. glabra and their hybrids and U. laevis) were inoculated with Ophiostoma novo-ulmi in comparison with some cultivars on two sites under six inoculation series. Crown wilt and defoliation percentage was assessed in the inoculation year, and subsequent recovery and mortality were also recorded. Multiple comparisons indicated that the results were reproducible. Species effect was generally detected, U. glabra being more susceptible than the other native species. Clone effect was always very significant with a wide symptom amplitude between clones, particularly among $U$. minor. In the case of $U$. laevis, some clones suffered high mortality rates, whereas other showed a strong recovery ability. Clones with a good behaviour could be identified among each species. Some of them showed complete recovery the year following inoculation. No effect of taxa and geographic origin was detected in the frequency of superior clones. Because no native elm clone reached the level of resistance of the best cultivars ('Sapporo Autumn Gold' ${ }^{\circledR}$ and 'LUTECE ${ }^{\circledR}$ Nanguen'), their cultivation in pure stand is not recommended. However, the best clones can be introduced in multi-species plantations, especially for the reconstruction of countryside hedges; they may also contribute to a breeding programme.
\end{abstract}

Ulmus / species / clone / susceptibility / Ophiostoma novo-ulmi

Résumé - Sensibilité envers Ophiostoma novo-ulmi de clones d'orme d'origine française. Plus de 200 clones d'ormes indigènes en Europe (U. minor, U. glabra et leurs hybrides et U. laevis) ont été inoculés avec Ophiostoma novo-ulmi en comparaison avec quelques cultivars sur deux sites et au cours de six séries d'inoculations. Le pourcentage de flétrissement ou de défeuillaison a été estimé l'année de l'inoculation, et la guérison ou la mortalité ultérieures ont aussi été notées. Des comparaisons multiples indiquent que les résultats sont reproductibles. L'effet espèce est généralement significatif, $U$. glabra étant l'espèce indigène la plus sensible. L'effet clone est toujours très significatif et une large gamme de comportement est mise en évidence, notamment chez U. minor. U. laevis révèle des clones à forte mortalité alors que d'autres présentent de bonnes facultés de récupération. Du fait de l'effet clone, il est possible au sein de chaque espèce de distinguer des clones de bon comportement. Celui-ci se traduit notamment par des guérisons complètes en deuxième année après l'inoculation. La fréquence de ces clones ne semble pas liée à l'espèce ni à l'origine géographique. Ces clones indigènes n'offrent cependant pas le niveau de résistance des meilleurs cultivars ('Sapporo Autumn Gold' ${ }^{\circledR}$ et 'LUTECE ${ }^{\circledR}$ Nanguen') et de ce fait leur culture en plantation monospécifique ou monoclonale ne peut être recommandée. Ils pourraient toutefois être utilisés avec prudence dans des plantations multispécifiques, notamment pour la reconstitution de haies, voire intégrés dans un programme d'amélioration.

Ulmus / espèce / clone / sensibilité / Ophiostoma novo-ulmi

\section{INTRODUCTION}

Elm populations have been severely damaged in France by the two successive Dutch elm disease (DED) outbreaks which swept the country in the 1920s and 1970s respectively. Many indigenous trees which had survived the first epidemic were killed in the second, owing to aggressive strains of Ceratocystis ulmi (Buism.) Nannf. Gibbs et al. [4] later described as a distinct species, Ophiostoma novo-ulmi Brasier [1]. For instance, the number of adult elm trees in Paris has decreased from 30000 (half of them in the Bois de Vincennes) in 1970 to little more than 1000 today (not one remains in the Bois de Vincennes). Severe losses occurred also in the countryside [13]. Control measures against the fungus (trunk injection of fungicide) or against the insect vectors have had only a small effect and their application was very limited [12]. Consequently, plant resistance to the fungus is still the most promising prospect.

Sources of resistance have been identified by Heybroek [6] and Lester et al. [8] in several Asiatic elm species. Smalley and Lester [18] released the first hybrid cultivar resistant to the aggressive strains, 'Sapporo Autumn Gold' ${ }^{\circledR}$. However, the Asiatic elm species differ from the European ones (Ulmus minor Miller, U. glabra Hudson and $U$. laevis Pallas) in many aspects, and only $U$. pumila L. has been cultivated for a long period in the south of Europe. A general overview of breeding elms for resistance can be found in Smalley and Guries [16] and Mittempergher and Santini [10]. The Dutch breeding programme, which lasted over 64 years [7], involved many interspecific crosses between Asian and European species and resulted in several highly resistant hybrid cultivars released

\footnotetext{
* Corresponding author: pinon@ nancy.inra.fr
} 


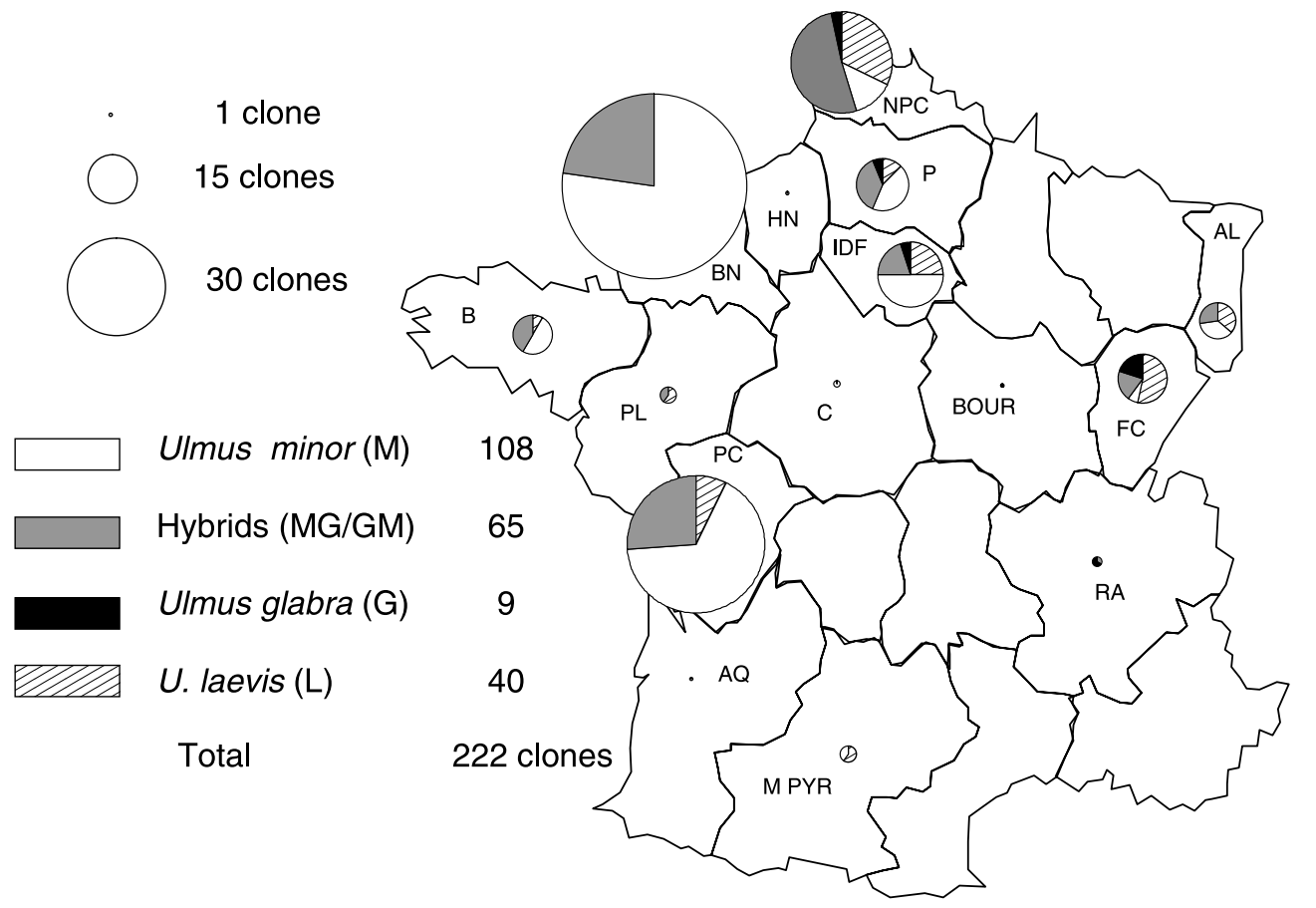

Figure 1. Origins of the native French elm clones tested for susceptibility to Ophiostoma novoulmi. AL: Alsace, AQ: Aquitaine, B: Bretagne, BN: Basse-Normandie, BOUR: Bourgogne, C: Centre, FC: Franche-Comté, HN: HauteNormandie, IDF: Ile-de-France, M PYR: Midi-Pyrénées, NPC: NordPas-de-Calais, P: Picardie, PL: Paysde-la-Loire, RA: Rhône-Alpes. onto the market. In addition, other promising hybrid clones supplied by Heybroek have been tested in many European institutes since 1981. Some of these clones proved to be very resistant to repeated inoculations, even when their parentage is mainly European [14].

Some resistance can also be expected to be found in the native European adult elms which survived the second outbreak of DED. However, the reasons for survival are not clear. A greater chance of escape from DED can be expected in the case of trees isolated from other elms, whereas some resistance to the fungus and/or a lack of attractiveness to the insect vector can be suspected in heavily diseased areas. To test the resistance hypothesis, plants of clones obtained from old surviving trees were subjected to artificial inoculation in experiments conducted in Nancy (Meurthe-et-Moselle) and Nogent-sur-Vernisson (Loiret). Symptom development and ability to recover were studied, and the main results are presented in this paper.

\section{MATERIALS AND METHODS}

\subsection{Plant material}

With the exception of the hybrid cultivars used as control clones and some Romanian material conserved by Cemagref, the clones under test are part of the collection created by Cemagref in the context of the French programme for the conservation of Elm genetic resources [2, 3]. Altogether, 222 different native French elm clones were inoculated, originating from many regions of France, but mostly from the north-west (Fig. 1). The material was principally collected from forests and countryside hedges, but some roadside and park trees were also included. Classification of the botanical type of clones was based on leaf and bud characters. Molecular characterisation based on RAPDs and ISSRs markers [5] was available for some clones, facilitating confirmation or refinement of the morphological assignment.
U. laevis, which does not hybridise with the two other native European species [9], is clearly distinct from them. Conversely, U. minor and $U$. glabra exchange genes in regions where they are sympatric and form a species complex in which distinctions between the two pure species and their natural hybrids are not clear-cut [5]. In this study, two types of hybrids were recognised: hybrids in which $U$. minor characteristics predominated (designated as minor $>$ glabra) and hybrids in which U. glabra characteristics predominated (glabra $>$ minor). Two other clones collected in France and included in the tests were found to be allochtonous material, probably belonging to an Asian species. In addition, eleven clones propagated by Cemagref from seedlings harvested in Romania by G. F. Borlea from two trees (one U. glabra and one U. minor) were inoculated together with the French material.

At Nancy in 1998 (Na98) and in Nogent in 2001 (Tal01 and Pep01) hybrid cultivars were added as resistant control clones. The most resistant ones are 'Sapporo Autumn Gold ${ }^{\circledR}($ U. pumila $\times$ U. japonica Sarg.) and the latest complex Dutch hybrids obtained by H. Heybroek and recently selected by INRA for their resistance: '762', '812' (registered as 'LUTECE ${ }^{\circledR}$ Nanguen'), '1012', '1016', '1038' and '1094'. Two Dutch cultivars from earlier breeding generations ('Commelin', 'Lobel') were added in Nogent-nursery experiment, to serve as low and fair resistance control clones. All clones were propagated by cuttings.

\subsection{Methods}

\subsubsection{Plantation}

Between January 1993 and December 1999, over 2500 two-yearold plants were planted in four field trials (Tab. I). The first two plantations took place in the INRA nursery in the vicinity of Nancy (Na95, $\mathrm{Na} 98$ and $\mathrm{NaO0}=\mathrm{Na} 95$ partly reinoculated in 2000), the last ones in an experimental field (Tal00 and Tal01) and in the nursery (Pe01) of Cemagref in Nogent-sur-Vernisson. In all cases except the last, the soil type did not enable rapid growth of the plants, and plant replacements by trees of the same age were needed in the Nogent-field plantation. In the Nogent-nursery test, automatic watering resulted in better 
Table I. Distribution of inoculated native elm clones according to their botanical type.

\begin{tabular}{|c|c|c|c|c|c|c|c|c|}
\hline \multirow[b]{3}{*}{ Experiment } & \multirow[b]{3}{*}{$\begin{array}{c}\text { Field trial } \\
\text { plantation date }\end{array}$} & \multirow[b]{3}{*}{$\begin{array}{l}\text { Inoculation } \\
\text { date }\end{array}$} & \multicolumn{6}{|c|}{ Number of clones (of trees) } \\
\hline & & & \multirow[b]{2}{*}{ U. minor } & \multicolumn{2}{|c|}{$\begin{array}{c}\text { Hybrids } \\
\text { U. minor } \times \text { U. glabra }\end{array}$} & \multirow[b]{2}{*}{ U. glabra } & \multirow[b]{2}{*}{ U. laevis } & \multirow[b]{2}{*}{ Total } \\
\hline & & & & $\begin{array}{l}\text { U. minor }> \\
\text { U. glabra* }\end{array}$ & $\begin{array}{l}\text { U. glabra }> \\
\text { U. minor** }\end{array}$ & & & \\
\hline Na95 & Jan. 1993 & 23 May 1995 & $25(140)$ & $3(18)$ & $4(23)$ & $1(3)$ & 0 & $33(184)$ \\
\hline $\mathrm{Na} 00$ & & 29 May 2000 & $25(158)$ & $3(19)$ & $4(24)$ & $1(3)$ & 0 & $33(204)$ \\
\hline $\mathrm{Na} 98$ & $\begin{aligned} & \text { Feb. } 1994 \\
+ & \text { March } 1995\end{aligned}$ & 26-27 May 1998 & $42(267)$ & $16(99)$ & $5(32)$ & $3(13)$ & $9(43)$ & $75(454)$ \\
\hline Tal00 & April 1996 & 23 May 2000 & $28(103)$ & $12(42)$ & $12(35)$ & $4(15)$ & $11(43)$ & $67(238)$ \\
\hline Tal01 & + March 1997 & 5 June 2001 & $30(87)$ & $11(26)$ & $10(24)$ & $3(6)$ & $16(36)$ & $70(179)$ \\
\hline $\mathrm{Pe} 01$ & March + Dec. 1999 & 5 June 2001 & $6(42)$ & $5(33)$ & $4(25)$ & $1(8)$ & $12(81)$ & $28(189)$ \\
\hline
\end{tabular}

Hybrids: * morphologically closer to U. minor, ** morphologically closer to U. glabra.

growth, and the inoculation height (at least $2 \mathrm{~m}$ ) was reached in 2 or 3 years according to species and clone vigour.

\subsubsection{Experimental plot}

Randomised single tree plots ( 5 or 9 trees per clone) were used, except for Nogent-nursery ( 2 blocks, 8 trees per clone). Distances between plants varied from $2 \mathrm{~m} \times 2 \mathrm{~m}$ (Nogent-field) to $0.7 \mathrm{~m}(1.4 \mathrm{~m}$ between clones) $\times 2.4 \mathrm{~m}$ (Nogent-nursery).

\subsubsection{Inoculations}

Inoculations were conducted during the period of maximum susceptibility of the elms (Tab. I), i.e. late May in northern France, using a fresh culture. The fungus was isolated at the end of April on malt extract agar from a naturally-infected tree before each set of inoculations. Subcultures were prepared on liquid Tchernoff's media [20] shaken at room temperature for three days. Inoculations were performed by wounding the main stem with a knife. A drop of spore suspension was deposited on the blade of the knife and the tree wounded until active absorption of the spore suspension by the xylem vessels. Inoculations were performed at breast height in Nancy and at approximately $2 / 3$ of the plant height in Nogent-sur-Vernisson.

$\mathrm{Na} 95$ was re-inoculated in May $2000(\mathrm{Na} 00)$ because of the relatively mild reaction to the May 1995 inoculation and generally good recovery and survival. Owing to species and clone differences in growth speed, not all the clones of each Nogent test could be inoculated in the same year.

\subsubsection{Assessments}

Tree height was measured in the autumn before inoculation. Diameter at $1.3 \mathrm{~m}$ height was also measured in Tal00. Symptoms were generally assessed four and ten weeks after inoculation. In Nancy experiments, symptoms were expressed in percentage of symptomatic twigs, whereas in Nogent a scale with eight infection classes was used to assess the proportion of symptoms (wilt and defoliation) affecting the crown of each tree. Classes were defined as: $1=$ no symptom, $2=$ 1 to $10 \%$ symptomatic, $3=11$ to $25 \%, 4=26$ to $33 \%, 5=34$ to $50 \%$, $6=51$ to $75 \%, 7=76$ to $99 \%$ and $8=100 \%$. For calculations the middle value of each class was used (respectively: $0,5.5,18,29.5,42,63,87.5$ and $100 \%$ ).

During the following year, no re-inoculation was performed and trees were assessed one or two times during the growing season, allowing an evaluation of the ability to recover. Mortality was assessed the third year in Tal00.
In the Nogent tests, a more precise method for the second year symptom assessment was developed. Each tree received two scores evaluating: (1) the percentage of the crown that had been able to flush and grow (score 1); (2) the subsequent wilting and defoliation percentage of the new shoots (score 2). Those two scores were combined to determine the global recovery score calculated as below:

Second year score (between 0 and 100) $=$

$(100$ - score 1$)+($ score $1 \times$ score 2$) / 100)$.

Each score was taken as the middle value of the class, respectively for classes 1 to 8 : $0,5.5,18,29.5,42,63,87.5$ and 100 .

\subsubsection{Data analysis}

All percentages were transformed as $\operatorname{Arcsin} \sqrt{\%}$ before ANOVA computing. For species comparison, the mean value of each clone was used to avoid the potential effect of the different numbers of plants per clone. Plant height before inoculation had a significant effect only in $\mathrm{Na} 95$ and therefore it was introduced as a covariate in the relevant ANOVA. Differences between the native species were sometimes relatively small and $U$. glabra represented by a small number of clones. Therefore data for the hybrids were often combined with those of their more similar parent: for example hybrids glabra $>$ minor and $U$. glabra. The resulting group was designated as $U$. glabra lato sensu. A distinct ANOVA was computed and the results presented in the lower part of the tables. Correlations were calculated according to Pearson's coefficient. For frequency comparison, Chi-Square test was used.

\section{RESULTS}

\subsection{Methodological aspects}

\subsubsection{Relationships between assessors}

In two experiments (three assessments altogether), data from different assessors were compared. In the 27 June assessment of $\mathrm{Na} 00$, all correlation coefficients between the four assessors were comprised between 0.86 and 0.93 and were highly significant $(P<0.0001)$. In the same experiment, on 8 August ( 3 assessors), coefficients varied between 0.88 and $0.91(P<0.0001)$. In Tal01, on 9 July 2001, correlation coefficients between the 3 assessors were comprised between 0.90 and 0.92 and were highly significant $(P<0.0001)$. When several assessors were involved, tree value was calculated as the mean of assessor scores. 
Table II. Relationship (correlation coefficients) between symptoms in Nancy on clones inoculated in 1995 and in 2000.

\begin{tabular}{|c|c|c|c|c|c|}
\hline & $\begin{array}{l}\text { May } \\
1996\end{array}$ & $\begin{array}{c}\text { 4-5 September } \\
1997\end{array}$ & $\begin{array}{l}4 \text { July } \\
2000\end{array}$ & $\begin{array}{l}29 \text { August } \\
2000\end{array}$ & $\begin{array}{l}18 \text { July } \\
2001\end{array}$ \\
\hline 7-8 August 1995 & $0.68 * * *$ & 0.31 & \multirow{5}{*}{$\begin{array}{l}\mathbf{0 . 3 8}{ }^{*} \\
\mathbf{0 . 6 0} 0^{* * *} \\
0.11\end{array}$} & $0.38 *$ & 0.19 \\
\hline May 1996 & & $0.58 * * *$ & & 0.29 & $0.46 * *$ \\
\hline 4-5 September 199 & & & & -0.09 & 0.02 \\
\hline 4 July 2000 & & & & $0.71 * * *$ & $0.41 *$ \\
\hline 29 August 2000 & & & & & 0.18 \\
\hline
\end{tabular}

Significant correlation coefficient in bold: $* 5 \%, * * 1 \%, * * * 1 \%$ confidence level. Inside frames, comparison within an inoculation set.

\subsubsection{Tree vigour}

Tree vigour is often considered to have an effect on symptom development (Heybroek, personal communication). Vigour is usually thought to be important within a clone, trees growing vigorously developing more symptoms. In $\mathrm{Na} 95$ a positive and significant relationship was found in 1995 and $1996(r=0.18$ and 0.19 respectively; $P=0.01$ ) between initial height and symptom development, suggesting that vigorous trees may develop more symptoms. This initial relationship disappeared later. No significant effect of height was detected in the other experiments. Diameter was also measured at Nogent (experimental batch inoculated in 2000) and values were compared with symptom assessment on 27 June, 8 August and 19 September of the same year; again, no significant relationship was detected.

\subsubsection{Relationship between two sets of inoculation on the same trees}

Most of the trees inoculated in Nancy in 1995 later recovered. They were inoculated a second time in 2000, which allowed comparison of symptom expression on the same trees in reaction to two sets of inoculations (Tab. II). Trees still symptomatic or in too poor condition in 2000 as a consequence of 1995 inoculation were not tested. Within a test, the values of the correlation coefficients tend to decrease with time, indicating different evolutions between clones.

When comparing inoculations, the first assessments for two different inoculations (1995/2000) were significantly related; this was also the case when second year assessments were compared (1996/2001).

\subsection{Variability of susceptibility between species}

\subsubsection{Wilting}

In Na95 U. glabra lato sensu was significantly more susceptible than U. minor in 1995 but later was indistinct. In Na00 U. glabra lato sensu was significantly more susceptible at all assessments in 2000 and 2001.
Table III. Wilting symptoms for various elm species and hybrids inoculated in 1998 (Na98). Values with the same letter did not differ significantly $(P<0.05)$.

\begin{tabular}{|c|c|c|c|c|}
\hline Probability & $\begin{array}{c}22 \text { June } \\
1998 \\
P<0.0001\end{array}$ & $\begin{array}{l}24 \text { August } \\
1998 \\
P<0.0001\end{array}$ & $\begin{array}{c}24 \text { June } \\
1999 \\
P=0.0007\end{array}$ & $\begin{array}{c}6 \text { September } \\
1999 \\
P=0.008\end{array}$ \\
\hline \multicolumn{5}{|l|}{ Elm } \\
\hline Dutch hybrids* & $2.5 \mathrm{a}$ & $5.9 \mathrm{a}$ & $0.1 \mathrm{a}$ & $0 \mathrm{a}$ \\
\hline $\begin{array}{l}U . \times \text { hollandica } \\
\text { 'Commelin' }\end{array}$ & $45.3 \mathrm{~b}$ & $73.9 \mathrm{bc}$ & $55.7 \mathrm{bc}$ & $53.9 \mathrm{~b}$ \\
\hline U. laevis & $42.2 \mathrm{~b}$ & $68.9 \mathrm{bc}$ & $23.6 \mathrm{ab}$ & $29.0 \mathrm{~b}$ \\
\hline U. minor & $48.0 \mathrm{~b}$ & $60.8 \mathrm{~b}$ & $35.4 \mathrm{bc}$ & $38.4 \mathrm{~b}$ \\
\hline $\begin{array}{l}\text { Hybrid } U . \text { minor }> \\
U . \text { glabra }\end{array}$ & $51.8 \mathrm{~b}$ & $60.8 \mathrm{~b}$ & $36.6 \mathrm{bc}$ & $37.3 \mathrm{~b}$ \\
\hline $\begin{array}{l}\text { Hybrid } U \text {. glabra }> \\
\text { U. minor }\end{array}$ & $52.7 \mathrm{~b}$ & $73.3 \mathrm{c}$ & $55.1 \mathrm{c}$ & $51.2 \mathrm{~b}$ \\
\hline U. glabra & $42.6 \mathrm{~b}$ & $59.1 \mathrm{bc}$ & $53.0 \mathrm{bc}$ & $48 \mathrm{~b}$ \\
\hline \multicolumn{5}{|c|}{ Native species lato sensu } \\
\hline Probability & NS & $P<0.0001$ & $P=0.004$ & $P=0.009$ \\
\hline \multicolumn{5}{|l|}{ Elm } \\
\hline U. laevis & 42.2 & $68.9 \mathrm{~b}$ & $23.6 \mathrm{a}$ & $29.0 \mathrm{a}$ \\
\hline U. minor & 49.0 & $60.8 \mathrm{a}$ & $35.7 \mathrm{~b}$ & $38.1 \mathrm{a}$ \\
\hline U. glabra & 48.9 & $67.9 \mathrm{~b}$ & $54.3 \mathrm{c}$ & $50.0 \mathrm{~b}$ \\
\hline
\end{tabular}

$\mathrm{NS}=$ non significant.

* '762'. '812' (='LUTECE ${ }^{\circledR}$ Nanguen'). '1012'. '1026'. '1038' and '1094'.

In Nancy in 1998 (Na98) 75 native clones (Tab. I) were compared with several relatively recent Dutch hybrids already selected for their high level of resistance and listed in Section 2.1, and at all dates, these latter clones were much more resistant (Tab. III). Some significant differences were observed between the native species and also between the native species and their hybrids. U. glabra lato sensu (as defined in Sect. 2.2.5) exhibited always more symptoms than the two other species and was significantly the most susceptible at three assessments. Symptoms developed more slowly on U. laevis but finally it was indistinct from U. minor. The susceptibility of the early Dutch hybrid 'Commelin' was confirmed.

In Nogent in 2000 (Tal00) no significant effects could be detected at the two first assessments, all taxonomic groups showing severe wilt (Tab. IV). In September U. minor and the $U$. minor dominant hybrids were significantly less diseased than the other taxa (U. glabra and U. laevis) and the difference could be still observed in 2001.

A second part of the Nogent experimental batch (Tal01) was inoculated in 2001 (Tab. V). Sapporo never exhibited symptoms. A clone of unknown origin, putatively Asian or hybrid, was found less symptomatic than most of the European native clones. U. laevis and U. minor hybrids performed best at the first assessment but $U$. laevis deteriorated markedly by the time of the second assessment. U. glabra lato sensu was significantly more symptomatic at the first two assessments but was indistinct from the two other species during the second year. In 2002 differences between species were not significant. 
Table IV. Wilting symptoms for various elm species and hybrids inoculated in 2000 (Tal00). Values with the same letter did not differ significantly $(P<0.05)$.

\begin{tabular}{|c|c|c|c|c|c|c|}
\hline $\begin{array}{l}\text { Assessment date } \\
\text { Probability }\end{array}$ & $\begin{array}{c}27 \text { June } 2000 \\
\text { NS }\end{array}$ & $\begin{array}{c}8 \text { August } 2000 \\
\text { NS }\end{array}$ & $\begin{array}{c}19 \text { September } 2000 \\
P=0.0003\end{array}$ & $\begin{array}{c}10 \text { July } 2001 \\
P=0.002\end{array}$ & $\begin{array}{c}29 \text { August } 2001 \\
P<0.0001\end{array}$ & $\begin{array}{c}24 \text { June } 2002 \\
P<0.0001\end{array}$ \\
\hline \multicolumn{7}{|l|}{ Elm } \\
\hline U. laevis & 52.6 & 78.4 & $92.3 \mathrm{bc}$ & $33.8 \mathrm{bc}$ & $92.4 \mathrm{~b}$ & $84.3 \mathrm{~b}$ \\
\hline U. minor & 57.7 & 82.1 & $69.9 \mathrm{a}$ & $14.9 \mathrm{a}$ & $68.2 \mathrm{a}$ & $51.3 \mathrm{a}$ \\
\hline Hybrid $U$. minor $>U$. glabra & 50 & 70.3 & $71.4 \mathrm{a}$ & $17.9 \mathrm{ab}$ & $72.1 \mathrm{a}$ & $58.4 \mathrm{a}$ \\
\hline Hybrid $U$. glabra $>U$. minor & 46.3 & 72 & $80.5 \mathrm{ab}$ & $39.6 \mathrm{c}$ & $89.2 \mathrm{~b}$ & $83.2 \mathrm{~b}$ \\
\hline U. glabra & 44.3 & 76.4 & $99.1 \mathrm{c}$ & $29.3 \mathrm{abc}$ & $96.1 \mathrm{~b}$ & $90.6 \mathrm{~b}$ \\
\hline \multicolumn{7}{|c|}{ Species lato sensu } \\
\hline Probability & NS & NS & $P=0.0013$ & $P=0.0004$ & $P<0.0001$ & $P=0.0003$ \\
\hline \multicolumn{7}{|l|}{ Elm } \\
\hline U. laevis & 52.6 & 78.4 & $92.3 \mathrm{~b}$ & $33.8 \mathrm{~b}$ & $92.4 \mathrm{~b}$ & $84.3 \mathrm{~b}$ \\
\hline U. minor & 55.6 & 79 & $70.3 \mathrm{a}$ & $15.7 \mathrm{a}$ & $69.3 \mathrm{a}$ & $53.3 \mathrm{a}$ \\
\hline U. glabra & 45.9 & 73.1 & $86.8 \mathrm{~b}$ & $37.1 \mathrm{~b}$ & $91.1 \mathrm{~b}$ & $85.1 \mathrm{~b}$ \\
\hline
\end{tabular}

NS = non significant.

Table V. Wilting symptoms for various elm species and hybrids inoculated in 2001 (Tal01). Values with the same letter did not differ significantly $(P<0.05)$.

\begin{tabular}{|c|c|c|c|}
\hline $\begin{array}{l}\text { Assessment date } \\
\text { Probability }\end{array}$ & $\begin{array}{c}9 \text { July } 2001 \\
P=0.002\end{array}$ & $\begin{array}{c}28 \text { August } 2001 \\
P<0.0001\end{array}$ & $\begin{array}{c}24 \text { June } 2002 \\
\text { NS }\end{array}$ \\
\hline \multicolumn{4}{|l|}{ Elm } \\
\hline 'Sapporo' & $0 \mathrm{a}$ & $0 \mathrm{a}$ & 0 \\
\hline Exotic & $19.3 \mathrm{abc}$ & $35.5 \mathrm{abc}$ & 23.7 \\
\hline U. laevis & $36.5 \mathrm{ab}$ & $59.6 \mathrm{bc}$ & 46.7 \\
\hline$U$. minor & $43.2 \mathrm{bc}$ & $55.6 \mathrm{ab}$ & 49.6 \\
\hline Hybrid minor $>$ glabra & $27.8 \mathrm{a}$ & $44.5 \mathrm{a}$ & 40.9 \\
\hline Hybrid glabra $>$ minor & $53.8 \mathrm{c}$ & $68.7 \mathrm{c}$ & 63.2 \\
\hline U. glabra & $61.2 \mathrm{bc}$ & $60.9 \mathrm{abc}$ & 48 \\
\hline \multicolumn{4}{|c|}{ Native species lato sensu } \\
\hline Probability & $P=0.03$ & $P<0.0001$ & NS \\
\hline \multicolumn{4}{|l|}{ Elm } \\
\hline U. laevis & $36.5 \mathrm{a}$ & $59.6 \mathrm{ab}$ & 46.7 \\
\hline$U$. minor & 38.9 a & $52.6 \mathrm{a}$ & 47.2 \\
\hline U. glabra & $55.5 \mathrm{~b}$ & $66.9 \mathrm{~b}$ & 59.7 \\
\hline
\end{tabular}

$\mathrm{NS}=$ non significant.

In Pe01 (Tab. VI), native clones were compared with some cultivars exhibiting known levels of resistance: 'Sapporo Autumn Gold' ${ }^{\circledR}$ (high), 'Lobel' (fair) and 'Commelin' (low). 'Sapporo Autumn Gold' ${ }^{\circledR}$ confirmed its high level of resistance (no symptoms), while the two other cultivars were intermediate. In 2001 U. laevis appeared more susceptible than the two other species (lato sensu) and was always significantly distinct from $U$. minor lato sensu. The second year, no significant differences were found between taxa lato sensu.

\subsubsection{Mortality}

Another way to compare species was to take tree mortality during the second or the third year after inoculation into
Table VI. Wilting symptoms for various elm species and hybrids inoculated in 2001 (Pe01). Values with the same letter did not differ significantly $(P<0.05)$.

\begin{tabular}{|c|c|c|c|}
\hline $\begin{array}{l}\text { Assessment date } \\
\text { Probability }\end{array}$ & $\begin{array}{l}9 \text { July } 2001 \\
P<0.0004\end{array}$ & $\begin{array}{l}28 \text { August } 2001 \\
P<0.0001\end{array}$ & $\begin{array}{c}24 \text { June } 2002 \\
P=0.0054\end{array}$ \\
\hline \multicolumn{4}{|l|}{ Elm } \\
\hline ‘Sapporo’’ & $0 \mathrm{a}$ & $0 \mathrm{a}$ & - \\
\hline ‘Commelin’ & $5.5 \mathrm{ab}$ & $24.5 \mathrm{~b}$ & $49.8 \mathrm{abc}$ \\
\hline 'Lobel’' & $10.1 \mathrm{abc}$ & $11.3 \mathrm{ab}$ & $13.1 \mathrm{a}$ \\
\hline U. laevis & $39.3 \mathrm{de}$ & $81.3 \mathrm{~d}$ & $79.9 \mathrm{c}$ \\
\hline U. minor & $51 \mathrm{e}$ & $65 \mathrm{c}$ & $75 \mathrm{bc}$ \\
\hline Hybrid minor $>$ glabra & 37.4 cde & $66.2 \mathrm{c}$ & $45.0 \mathrm{ab}$ \\
\hline Hybrid glabra $>$ minor & $26.1 \mathrm{bcd}$ & $74.6 \mathrm{~cd}$ & $78.1 \mathrm{bc}$ \\
\hline U. glabra & $5.5 \mathrm{ab}$ & $43 \mathrm{bc}$ & $56.2 \mathrm{abc}$ \\
\hline \multicolumn{4}{|c|}{ Native species lato sensu } \\
\hline Probability & $P=0.02$ & $P=0.02$ & NS \\
\hline \multicolumn{4}{|l|}{ Elm } \\
\hline U. laevis & $39.3 \mathrm{~b}$ & $81.3 \mathrm{~b}$ & 79.9 \\
\hline$U$. minor & $44.8 \mathrm{a}$ & $65.6 \mathrm{a}$ & 61.9 \\
\hline U. glabra & $21.0 \mathrm{a}$ & $68.7 \mathrm{ab}$ & 74.1 \\
\hline
\end{tabular}

$\mathrm{NS}=$ non significant.

account. Mortality occurred mainly in Tal00, so only data from this experiment were examined. Significant differences occurred between species at the end of 2002 growth season (Tab. VII). The highest percentage of mortality was found in U. glabra (40\%), in hybrids with $U$. glabra characteristics $(37 \%)$ and in $U$. laevis (35\%). Mortality was low in U. minor $(6 \%)$ and in hybrids with $U$. minor characteristics $(12 \%)$.

There was a significant effect $(\mathrm{F}=55.8,240 \mathrm{df}, P<0.0001)$ of symptoms in August 2000 on mortality in 2002. Thus for the trees still alive at the end of 2002 the mean for symptoms in August 2000 had been $83 \%$, while for those that had died, the equivalent figure was $91 \%$. 
Table VII. Differences between the taxa in terms of mortality expressed as the values of $\chi^{2}$ test in Tal00 assessed in 2002.

\begin{tabular}{lcccc}
\hline $\begin{array}{l}\text { Botanical type } \\
(\% \text { mortality })\end{array}$ & $\begin{array}{c}\text { glabra }>\text { minor } \\
(37 \%)\end{array}$ & $\begin{array}{c}\text { Ulmus laevis } \\
(35 \%)\end{array}$ & $\begin{array}{c}\text { Ulmus minor } \\
(6 \%)\end{array}$ & $\begin{array}{c}\text { minor }> \\
\text { glabra }(12 \%)\end{array}$ \\
\hline $\begin{array}{l}\text { Ulmus glabra } \\
(40 \%)\end{array}$ & 0.02 & 0.05 & $4.6^{*}$ & $2.2^{*}$ \\
& & & & \\
& & & & \\
& & & & \\
& & Ulabra $>$ minor laevis & $18.2^{* *}$ & $6.9^{* *}$ \\
& & Ulmus minor & $6.5^{*}$ \\
& & & & 1.5 \\
\hline
\end{tabular}

* Significant difference at $1 \%, * *$ at $1 \%$ o confidence level.

\subsubsection{Recovery}

An important criterion for species comparison is total recovery (absence of symptoms) in the second and third years following inoculation. In 1997, the overall recovery of trees inoculated in Nancy in 1995 was 64\%. All U. glabra recovered but because only 3 trees were involved this data just reflect the behaviour of a clone. The comparison of $U$. minor and its two types of hybrid did not reveal significant differences.

In Na98 experiment, recovery was estimated in August 1998 and in June and September 1999. In August 1998, recovery was observed on only one $U$. minor tree. Species comparisons were ensured by Chi-square tests. In 1999 at both dates (June and September), U. minor recovered less than U. glabra and U. laevis (Fig. 2). In September, recovery was most frequent within U. laevis.

No species effect was found in Tal00 when recovery was assessed in 2002. The percentage of the plant crown able to flush and grow in spring 2002 was in average $56.1 \pm 1.9 \%$ for the trees which did not subsequently wilt in the same year and significantly less $(48.1 \pm 2.8 \%)$ for the others.

In Tal01, there was a significant effect of species on recovery $\left(\chi^{2}=11.34,5 \mathrm{df}, P=0.045\right)$. Recovery was significantly more frequent for the exotic trees and for $U$. laevis. No difference was found between $U$. minor and $U$. glabra and their hybrids. Crown flushing percentage in spring 2002 was significantly more important in the case of trees which did not subsequently wilt in the same year $(67.7 \pm 1.5 \%)$ than in the case of those which exhibited wilt $(56.7 \pm 1.8 \%)$.

\subsection{Variability of susceptibility between clones}

The variability between clones was obvious. With six experiments, comprising 22 symptom assessments, clone effect was significant (most often at $P<0.0001$ ) in all assessments except 2. The absence of clone effect was noticed in Nogent (Tal00 experiment) at the two first assessments but not later in 2000 . When species (lato sensu) were analysed separately significant clone effect was the most frequent in $U$. minor (in 20 assessments out of 22), intermediate in $U$. glabra (15/22 assessments) and less frequent in $U$. laevis (8/16 assessments).

Important differences between clones for their susceptibility were always detected (Fig. 3) covering most of the time the full expected range for symptom development. The exotic clone
RECOVERY IN NANCY (1998 inoculations)

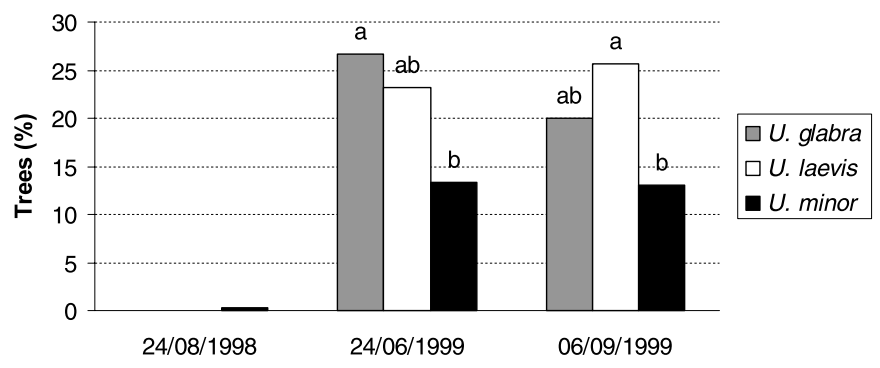

Figure 2. Percentage of un-symptomatic inoculated trees in Na98. Values with the same letter did not differ significantly $(P<0.05)$.

tested was less symptomatic than native clones, confirming its putative Asiatic origin.

Since clone effect appears to be important, and because a few clones from each species were indeed found to be more resistant than other clones in the same species, a selection of clones was made using as the criterion the recovery of all trees one year after inoculation in at least one experiment. The selected clones are listed in Table VIII (upper part), by decreasing number of experiments and trees: eight $U$. minor, four $U$. laevis, two hybrids $U$. minor $>$ glabra, one hybrid $U$. glabra $>$ minor and one $U$. glabra. The best clones represent $7 \%$ of the total number of native clones under test. No significant difference was found for the proportion of superior clones between species $\left(\chi^{2}=\right.$ $0.86,4 \mathrm{df}, P=0.89)$. Geographic origin of the clones did not affect the probability to find good clones $\left(\chi^{2}=6.24,14 \mathrm{df}, P=\right.$ 0.96). Because mortality was the highest in Tal00, a few clones which completely recovered in the third year may be added to the list of clones of interest: FRA.US.0331, -0351 and -0362 (U. minor) and -0348 (U. laevis).

The lower part of Table VIII lists clones which did not achieve complete recovery during the second year but nevertheless consistently exhibited limited symptoms suggesting some tolerance (no tree was more than $10 \%$ symptomatic in the second year). Five were $U$. minor and one was a hybrid U. minor $>$ U. glabra.

\section{DISCUSSION}

The methods for inoculation and symptom assessment employed in this study can be considered safe as regards possible bias due to plant size or observer. Comparisons of assessors lead to the conclusion that there was no effect. Tree size at the time of inoculation had a slightly significant positive effect on symptom development in one test only. The 1995 inoculation and 2000 re-inoculation carried out on the same trees provided data that were well correlated when comparing symptoms assessed at the same period since inoculation. Hence, the strong clone effect found in this study can be regarded as a good indicator of the susceptibility of the plant material to $O$. novo-ulmi. Further research should however investigate the effects of site, climate and inoculation date on symptom expression, mortality and recovery. Solla and Gil [19] 


\section{Symptom amplitude between clones}

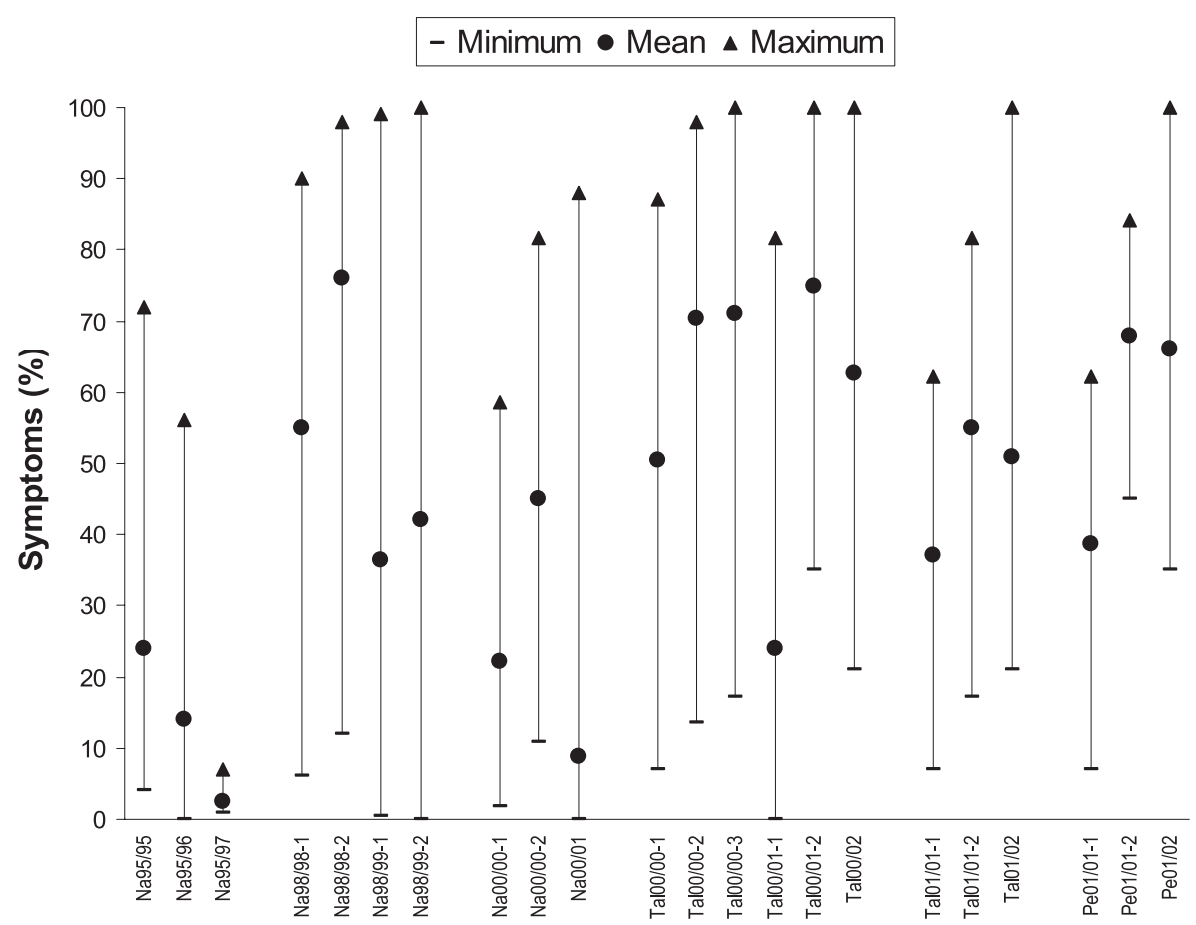

Figure 3. Variability between clones for symptom expression. _ clone with minimal symptoms, $\boldsymbol{\Delta}$ clone with maximal symptoms, $\bullet$ mean of all clones. For each assessment: test code/year of symptom assessment-rank in the year. proved that a generous watering regime enhanced symptom development. The period of greatest susceptibility of a given clone to $O$. novo-ulmi is only a few weeks and probably not exactly within the same period for all clones owing to clone variation in bud burst phenology according to Smalley and Kais [17]. Tchernoff [20] described mainly a species effect, U. americana being susceptible earlier than $U$. pumila and U. carpinifolia. In this study, all the material was inoculated at the same time during the average period of greatest susceptibility of native elms. This period lasts 20 days according to Smalley and Kais [17] to 30 days for Tchernoff [20].

In spite of the severe wilting of all the native elms tested, mortality was surprisingly low in all the experiments. This result does not seem consistent with the enormous damage caused in nature by the DED epidemics. Three reasons are likely to account for such a discrepancy: (i) the young plants in the tests have a greater capability than old trees to produce vigorous shoots from the lower part of the stem unaffected by the disease; (ii) mortality in nature has been overestimated owing to the false assumption that a tree with a dead trunk is a dead tree, irrespective of its ability to re-sprout from the stump; (iii) the clones in the test have a superior resistance because they were generally propagated from old trees which had survived the natural selection process in the second DED epidemic. It is probable that all three reasons have played a role and not possible to tell which has played the greatest one. Interestingly for conservation purposes, reason (ii) suggests that genotype losses in nature may have been over-estimated owing to the emotional impact of losing the old and beautiful structure of the tree, with no regard for subsequent regeneration. In terms of damage to landscape, the practical interest of making distinctions between 'dead' and 'able to re-sprout' can be questioned, especially when the lost elm is a magnificent old tree. In terms of gene conservation however, it is of major importance that genotype losses are properly assessed.

Comparison between species was somewhat difficult because $U$. minor was in the majority by far. Nevertheless some tendencies were quite consistent in most of the experiments. U. glabra was more susceptible than U. minor in Nancy (1995, 1998 and 2000) and Nogent $(2000,2001)$ with significant differences at least during inoculation's year. The same tendency was described by Smalley and Kais [17] and Smalley and Guries [16]. Symptom development was often slow in spring on $U$. laevis. Later its performance was sometimes intermediary between $U$. minor and $U$. glabra or similar to U. glabra. On some $U$. laevis trees, considerable wilt the first year was followed by recovery the second.

A comparison should be drawn now between clone behaviour under inoculation and the present state of health of the original old tree in nature. This would help to define a tolerance threshold and to identify healthy trees with low resistance to the fungus but with putative poor attractiveness for beetles. Some exploratory work has already been done by Webber and Kirby [21] and Piou (personal communication) but this matter needs more investigation.

The clone effect is strong enough to separate clones. Cultivars acted as useful controls. They reacted as expected: high resistance in 'Sapporo Autumn Gold" ${ }^{\circledR}$ and in the Dutch hybrids selected by INRA, intermediate resistance in 'Lobel' and low resistance in 'Commelin'. In natural material, it was possible to separate clones which are obviously very susceptible and clones which may be resistant enough for prudent use. Superior French clones were found in each taxa and each 
Table VIII. Clones with frequent recovery or limited symptoms the year following inoculation. Species: $\mathrm{G}=U$. glabra. $\mathrm{L}=U$. laevis. $M=U$. minor. Geographical origin: B: Bretagne, BN: Basse-Normandie, FC: Franche-Comté, IDF: Ile-de-France, P: Picardie, PC: Poitou-Charentes, PL: Pays-de-la-Loire, NPC: Nord-Pas-de-Calais.

\begin{tabular}{lcccc}
\hline Clone's number & $\begin{array}{c}\text { Number of } \\
\text { experiments }\end{array}$ & $\begin{array}{c}\text { Number of } \\
\text { trees }\end{array}$ & Species & Origin \\
\hline \multicolumn{5}{c}{ Total recovery } \\
FRA.US.0112 & $2 / 2$ & $4 / 4$ & $\mathrm{M}$ & $\mathrm{PC}$ \\
FRA.US.0009 & $2 / 3$ & $5 / 9$ & $\mathrm{MG}$ & $\mathrm{P}$ \\
FRA.US.0179 & $1 / 2$ & $16 / 18$ & $\mathrm{M}$ & $\mathrm{IDF}$ \\
FRA.US.0020 & $1 / 3$ & $12 / 14$ & $\mathrm{M}$ & $\mathrm{BN}$ \\
FRA.US.0035 & $1 / 1$ & $5 / 5$ & $\mathrm{M}$ & $\mathrm{BN}$ \\
FRA.US.0044 & $1 / 1$ & $5 / 5$ & $\mathrm{M}$ & $\mathrm{BN}$ \\
FRA.US.0072 & $1 / 2$ & $7 / 9$ & $\mathrm{M}$ & $\mathrm{BN}$ \\
FRA.US.0083 & $1 / 1$ & $5 / 5$ & $\mathrm{M}$ & $\mathrm{BN}$ \\
FRA.US.0205 & $1 / 1$ & $5 / 5$ & $\mathrm{M}$ & $\mathrm{B}$ \\
FRA.US.0247 & $1 / 1$ & $5 / 5$ & $\mathrm{GM}$ & $\mathrm{FC}$ \\
FRA.US.0295 & $1 / 1$ & $5 / 5$ & $\mathrm{~L}$ & $\mathrm{PL}$ \\
FRA.US.0095 & $1 / 1$ & $4 / 4$ & $\mathrm{~L}$ & $\mathrm{PC}$ \\
FRA.US.0262 & $1 / 2$ & $5 / 11$ & $\mathrm{G}$ & $\mathrm{P}$ \\
FRA.US.0333 & $1 / 1$ & $3 / 3 *$ & $\mathrm{~L}$ & $\mathrm{NPC}$ \\
FRA.US.0334 & $1 / 1$ & $3 / 3$ & $\mathrm{~L}$ & $\mathrm{NPC}$ \\
FRA.US.0352 & $1 / 2$ & $3 / 4$ & $\mathrm{MG}$ & $\mathrm{B}$ \\
\hline & $\mathrm{Limited}$ symptoms & & \\
\hline FRA.US.0032 & 3 & 18 & $\mathrm{MG}$ & $\mathrm{BN}$ \\
FRA.US.0077 & 3 & 17 & $\mathrm{M}$ & $\mathrm{BN}$ \\
FRA.US.0024 & 2 & 18 & $\mathrm{M}$ & $\mathrm{BN}$ \\
FRA.US.0028 & 2 & 18 & $\mathrm{M}$ & $\mathrm{BN}$ \\
FRA.US.0056 & 2 & 15 & $\mathrm{M}$ & $\mathrm{BN}$ \\
FRA.US.0034 & 2 & 10 & $\mathrm{M}$ & $\mathrm{BN}$ \\
\hline
\end{tabular}

* A minimum of 3 trees per clone was adopted for this tabulation.

region. Romanian clones were quite susceptible. However at the same time, it must be noted that for some clones there was quite a large variability between individual plants, some exhibiting complete recovery while others were very symptomatic. Such clones are too unreliable for practical use. The best trees, within a clone, may have prevented fungus migration from one ring to the following as already described by Shigo and Tippett [15]. If their good performance is confirmed in new tests, the next question will be the use of the best native clones. Because no clone proved as resistant as the best hybrid cultivars (like 'LUTECE ${ }^{\circledR}$ Nanguen' or 'Sapporo Autumn Gold' $\left.{ }^{\circledR}\right)$, it would be risky to propagate and plant such clones in cities or parks in pure monoclonal or monospecific stands or lines. But there is an interest in many European countries in hedge plantation including mixing tree species and genus. The best clones could be candidates for the reconstruction of countryside hedges. Mixing them with other species, which cannot be infected with O. novo-ulmi, will reduce the chance of root-graft transmission of disease, a major way for disease transmission according to Neely and Himelick [11]. In addition, these clones will contribute pollen and seed and, in the long term, enhance the general resistance and dynamic conservation of the local elm genetic resource. Another possible use of the best clones is to include them in a breeding population.
Acknowledgements: The authors are grateful to Béranger Bertin, Isabelle Bilger, Damien Davy, Anthony Jeanneau, Arlette Schipfer, Guémené-Penfao (Loire-Atlantique) nursery, the Ministère de l'Agriculture et de la Pêche and the EU for grants (RES GEN CT 96-78), to John Gibbs and Dominique Piou for their assistance in the manuscript preparation and to Andrew Brookes for his kind linguistic assistance.

\section{REFERENCES}

[1] Brasier C.M., Ophiostoma novo-ulmi sp. nov., causative agent of current Dutch elm disease pandemics, Mycopathologia 115 (1991) $151-161$.

[2] Collin E., Orme, in: Teissier du Cros E. (Ed.), Conserver les ressources génétiques forestières en France, Min. Agriculture, Bureau des Ressources Génétiques, CRGF, INRA-DIC, 1999, pp. 46-47.

[3] Collin E., Elm, in: Teissier du Cros E. (Ed.), Forest Genetic Resources Management and Conservation: France as a Case Study, Min. Agriculture, Bureau des Ressources Génétiques, CRGF, INRA-DIC, 2001, pp. 38-39.

[4] Gibbs J.N., Heybroek H.M., Holmes F.W., Aggressive strain of Ceratocystis ulmi in Britain, Nature 5342 (1972) 121-122.

[5] Goodall-Copestake W.P., Hollingsworth M.L., Hollingsworth P.M., Jenkins G.I., Collin E., Molecular markers and ex situ conservation of the European elms (Ulmus spp.), Biol. Conserv. 122 (2005) 537-546.

[6] Heybroek H.M., The development of forest tree breeding in The Netherlands, Gov. For. Exp. Sta., Tokyo, Japan, 1974, pp. 30-39.

[7] Heybroek H.M., The Dutch elm breeding program, in: Sticklen M.B., Sherald J.L. (Eds.), Dutch elm disease research: cellular and molecular approaches, New York, Springer-Verlag, 1993, pp. 16-25.

[8] Lester D.T., Smalley E.B., Polk R.B., Interspecific hybridization for commercial production of disease-resistant elms, Proc. 8th Cent. For. Tree Improv. Conf., October 11-13, 1972, Columbia, Missouri, 1974, pp. 73-75.

[9] Mittempergher L., La Porta N., Hybridization studies in the Eurasian species of elm (Ulmus spp.), Silvae Genet. 40 (1991) 237-243.

[10] Mittempergher L., Santini A., The history of elm breeding, Invest. Agrar., Sist. Rec. For. 13 (2004) 161-178.

[11] Neely D., Himelick E.B., Rootgraft transmission of dutch elm disease in municipalities, Plant Dis. Rep. (1963) 83-85.

[12] Pinon J. (Ed.), La Graphiose de l'orme, Doss. Envir. INRA, 1993, $\mathrm{n}^{\circ} 7,60 \mathrm{p}$.

[13] Pinon J., Feugey L., La Graphiose de l'Orme : une maladie à causes bien identifiées, Rev. For. Fr. 5 (1994) 422-430.

[14] Pinon J., Lohou C., Cadic A., Hybrid elms, adaptability in Paris and behaviour towards Dutch elm disease, in: Proceedings of the International Symposium on Urban Tree Health, 22-26 September 1997, Paris, Acta Hortic. 496 (1998) 107-114.

[15] Shigo A., Tippett J.T., Compartimentalization of American elm tissues infected by Ceratocystis ulmi, Plant Dis. 65 (1981) 715-718.

[16] Smalley E.B., Guries R.P., Breeding elms for resistance to Dutch elm disease, Ann. Rev. Phytopathol. 31 (1993) 325-352.

[17] Smalley E.B., Kais A.G., Seasonal variations in the resistance of various elm species to Dutch elm disease, in: Breeding pest-resistant trees, Pergamon Press, 1966, pp. 279-292.

[18] Smalley E.B., Lester D.T., 'Sapporo Autumn Gold' elm, HortScience 8 (1973) 514-515.

[19] Solla A., Gil L., Influence of water stress on Dutch elm disease symptoms in Ulmus minor, Can. J. Bot. 80 (2002) 810-817.

[20] Tchernoff V., Methods for screening and for the rapid selection of elms for resistance to Dutch elm disease, Acta Bot. Neerl. 14 (1965) 409-452.

[21] Webber J.F., Kirby S.G., Host feeding preference of Scolytus scolytus, For. Com. Bull. 60 (1983) 47-49. 